\title{
FAKTOR-FAKTOR PENYEBAB TERJADINYA PERNIKAHAN USIA DINI SISWA
}

\author{
Oleh: \\ Nurwia $^{1)}$, La Ode Muharam ${ }^{2)}$, Abas Rudin ${ }^{3)}$ \\ 1) 2) 3) Jurusan Bimbingan dan Konseling \\ Fakultas Keguruan dan Ilmu Pendidikan, Universitas Halu Oleo \\ Email: n.nurwia@yahoo.com
}

\begin{abstract}
ABSTRAK
Tujuan penelitian ini adalah untuk mengetahui faktor-faktor penyebab terjadinya pernikahan usia muda pada siswa SMA Negeri 2 Mawasangka Tengah Kabupaten Buton Tengah. Penelitian ini adalah penelitian kualitatif yaitu penelitian yang bertujuan untuk memahami fenomena tentang apa yang dialami oleh subjek penelitian yang dilakukan secara holistik. Informasi dalam penelitian ini adalah satu orang guru BK, satu orang guru wali kelas dan 5 Orang mantan siswa SMA Negeri 2 Mawasangka Tengah. Hasil penelitian menunjukkan bahwa faktor-faktor penyebab terjadinya pernikahan usia muda siswa SMA Negeri 2 Mawasangka Tengah yaitu 1) ekonomi keluarga yang tergolong kategori kurang mampu, siswa bersedia menikah pada usia dini untuk membantuk ekonomi keluarga mereka, dengan pernikahan tersebut maka orang tua telah kehilangan tanggung jawab keuangan atas anak mereka 2) rendahnya kesadaran terhadap pentingnya pendidikan, rendahnya pemahaman tersebut dikarenakan rendahnya tingkat pendidikan orang tua dan anak 3) faktor pengaruh lingkungan tempat tinggal.
\end{abstract}

Kata Kunci: Faktor-faktor Penyebab Pernikahan, Usia Muda

\section{FACTORS CAUSING EARLY-AGE MARRIED OF THE STUDENTS}

\begin{abstract}
The purpose of the research was to find out factors causing early-age married of the students of SMA Negeri 2 Mawasangka Tengah, Middle Buton District. The purpose of this qualitative research was to understand the phenomenon of what were experienced by the subjects of the research. The research was carried out holistically. The informants of the research were 1 guidance and counseling teacher, 1 homeroom teacher, and 5 alumni of SMA Negeri 2 Mawasangka Tengah, Middle Buton District. The results of the research show that there are three factors causing early-age married in SMA Negeri 2 Mawasangka Tengah, Middle Buton District. they are as follow: 1) family economic factor, the condition in which the family is sosially have not enough income. Therefore, the students are willing to marry soon in order to help their parents from the burden of family economic condition. In addition to that, if one of their children has married, the parents will have less responsibility in financing their children 2) lack of awareness about the important of education 3) Influences from the environment factor.
\end{abstract}

Keywords: Factors Causing Married, Early-Age Married. 


\section{Pendahuluan}

Pernikahan atau pernikahan menurut Sidiq (dalam Shomad) adalah pertalian yang sah antara seorang lelaki dan seorang perempuan yang hidup bersama (bersetubuh) dan yang tujuannya membentuk keluarga dan melanjutkan keturunan, serta mencegah perzinaan dan menjaga ketentraman jiwa atau batin. Pada dasarnya dalam perkawinan seorang pria hanya memunyai seorang istri dan seorang wanita hanya boleh memiliki seorang suami.

Pada pasal I Bab I Undang-undang Nomor I Tahun 1974 (Tentang Perkawinan) dinyatakan bahwa perkawinan ialah ikatan lahir batin antara seorang pria dengan seorang wanita sebagai suami istri dengan tujuan membentuk keluarga atau rumah tangga yang bahagia dan kekal berdasarkan Ketuhanan Yang Maha Esa. Dalam Pasal 7 Undang-undang Nomor 1 Tahun 1974 ayat (1) menyatakan bahwa "perkawinan hanya diizinkan jika pihak pria sudah mencapai umur 19 (Sembilan belas) tahun dan pihak wanita sudah mencapai umur 16 (enam belas) tahun". Ketentuan batas umur ini, seperti disebutkan dalam Kompilasi Hukum Islam pasal 15 ayat (1) didasarkan kepada pertimbangan kemaslahatan keluarga dan rumah tangga perkawinan. Sejalan dengan prinsip yang diletakkan Undang-undang Perkawinan, bahwa calon suami telah masuk jiwa raganya agar dapat mewujudkan tujuan perkawinan secara baik tanpa berakhir pada perceraian dan mendapat keturunan yang baik dan sehat. Untuk itu, harus dicegah adanya perkawinan antara calon suami istri yang masih di bawah umur.

Papalia \& Olds (dalam Sungkuwula: 2015) mengemukakan usia terbaik untuk menikah bagi perempuan adalah 19-25 tahun dan laki-laki usia 20-25 tahun diharapkan sudah menikah. Ini adalah usia terbaik untuk menikah, baik untuk memulai kehidupan rumah tangga maupun untuk mengasuh anak pertama (the first time parenting). Selain untuk keutuhan rumah tangga dan mengasuh anak, usia yang tepat untuk menikah juga dipengaruhi oleh dukungan sosial dan budaya, termasuk budaya keluarga. Budaya yang memandang pernikahan dini sebagai keputusan yang baik, akan cenderung menjadikan para pemuda lebih cepat mengalami kesiapan menikah (Adhim dalam Novita, 2015: $15)$.

Pernikahan dini (early mariage) adalah suatu pernikahan formal atau tidak formal yang dilakukan di bawah usia 18 tahun. Suatu ikatan yang dilakukan oleh seseorang yang masih dalam usia muda atau pubertas disebut pula pernikahan dini (Sarwono, 2007: 15). Selanjutnya, Al Ghifari (2008: 98) berpendapat bahwa pernikahan usia dini adalah pernikahan yang dilaksanakan di usia remaja. Dalam hal ini, yang dimaksud dengan remaja adalah antara usia 10-19 tahun dan belum kawin.

Soemiyati (dalam Sari, Suwarsito dan Mustolikh. 2015: 1) menjelaskan bahwa pernikahan dini merupakan suatu perjalanan perikatan antara seorang laki-laki dan seorang wanita. Perjajian di sini bukan sembarang perjanjian seperti perjanjian jual beli atau sewa menyewa, tetapi perjanjian dalam nikah adalah merupakan perjanjian suci untuk membentuk keluarga antara seorang laki-laki dan seorang wanita. Selanjutnya, menurut Badan Kependudukan dan Keluarga Berencana Nasional (BKKBN, 2016) menyebut bahwa penyebab pernikahan dini di antaranya adalah pendidikan, faktor ekonomi, faktor budaya, faktor orang tua, faktor diri sendiri dan faktor lingkungan. Hal lain yang dapat menyebabkan siswa menikah pada usia dini yaitu budaya, pendidikan, ekonomi orang tua, diri sendiri dan lingkungan.

Pernikahan usia dini juga banyak mengundang masalah yang tidak diharapkan dikarenakan dari segi psikologisnya belum matang khususnya bagi perempuan. Perkawinan pada usia muda sering menimbulkan kegoncangan dalam kehidupan berumah tangga, ini disebabkan karena kurangnya kesiapan mental dan masih belum matang jiwa raganya untuk membina rumah tangga sehingga terjadi pertengkaran, kesalahpahaman atau selisih pendapat antara keduanya sehingga menimbulkan perceraian. Penyebab yang lain misalnya kecemburuan yang berlebihan, tidak adanya komunikasi yang baik serta masalah ekonomi (selama menikah masih dalam pengangguran) tidak bekerja, hal ini merupakan salah satu faktor yang sangat penting dalam hidup berumah tangga karena semua ini disebabkan pada waktu menikah usianya masih relatif muda.

Salah satu tujuan utama pernikahan menurut ajaran Agama Islam adalah akad yang dapat menghalalkan hubungan seks antara laki-laki dan perempuan. Melalui pernikahan, hati laki-laki dan perempuan diharapkan dapat menyalurkan hasrat seksualnya untuk mendapatkan kenikmatan, menjaga alat reproduksinya dan mendapatkan keturunan secara sah (Hussein, 2008: 5-6). Orang yang melaksanakan pernikahan hendaklah terdiri atas orang yang dapat memertanggungjawabkan 
apa yang diperbuatnya itu terhadap istri atau suaminya, terhadap keluarganya dan tentunya juga terhadap Allah SWT.

Pernikahan amat penting dalam kehidupan manusia, perseorangan maupun kelompok dengan jalan pernikahan yang sah, pergaulan laki-laki dan perempuan menjadi terhormat sesuai kedudukan manusia sebagai makhluk yang berkehormatan. Pergaulan hidup berumah tangga dibina dalam suasana damai, tenteram dan rasa kasih sayang suami dan istri. Anak keturunan dari hasil pernikahan yang sah menghiasi kehidupan keluarga dan sekaligus merupakan kelangsungan hidup manusia secara bersih dan berkehormatan (Basyir, 2004: 1). Mengingat betapa banyak dampak buruk dari pernikahan dini, maka sebaiknya seorang yang ingin menikah di usia dini berpikir ulang karena pernikahan pada usia dini bukan hanya menyatukan antara laki-laki dan perempuan selama 1 tahun atau 2 tahun saja melainkan diharapkan selamanya akan membentuk keluarga yang sakinah, mawaddah dan warahmah.

Dalam kenyataannya, masih banyak kita jumpai perkawinan usia muda atau di bawah umur, padahal perkawinan yang sukses membutuhkan kedewasaan tanggung jawab secara fisik maupun mental, untuk bisa mewujudkan harapan yang ideal dalam kehidupan berumah tangga. Peranan orang tua sangat besar artinya bagi psikologis anakanaknya. Keluarga adalah tempat pertama bagi tumbuh kembang anak sejak lahir hingga dewasa, pola asuh yang baik pada anak perlu ditanamkan pada setiap keluarga.

Perkawinan di usia dini juga masih berlangsung di Indonesia terkhusus bagi siswa di SMA Negeri 2 Mawasangka Tengah Kabupaten Buton Tengah. Berdasarkan data yang peneliti peroleh, di SMA Negeri 2 Mawasangka Tengah selama tahun 2018 terdapat 5 siswi yang berhenti sekolah yang disebabkan karena menikah dini. Pernikahan yang dilakukan oleh siswa di SMA Negeri 2 Mawasangka Tengah tentu memiliki faktor-faktor penyebab yang mendorong siswa sehingga ia melakukan pernikahan saat masih duduk di bangku sekolah.

Rahmi (dalam Novita, 2015 : 3) mengemukakan bahwa terdapat beberapa alasan seseorang untuk menikah seperti 1) untuk mendapatkan jaminan ekonomi, membentuk keluarga, mendapatkan keamanan emosi, harapan orang tua, melepaskan diri dari kesepian, menginginkan kebersamaan, memunyai daya tarik seksual serta untuk mendapatkan perlindungan.
Berdasarkan latar belakang tersebut, masalah pernikahan dini menarik untuk dikaji, sehingga mendorong peneliti untuk melakukan penelitian dengan judul faktor-faktor penyebab terjadinya pernikahan usia dini pada siswa SMA Negeri 2 Mawasangka Tengah Kabupaten Buton Tengah. Tujuan penelitian ini adalah untuk mengetahui faktor-faktor penyebab terjadinya pernikahan Usia dini di SMA Negeri 2 Mawasangka Tengah, Kabupaten Buton Tengah.

Poerwadarminta (1997: 813) yang menjelaskan usia muda (remaja) menurut bahasa adalah mulai dewasa, sudah mencapai umur untuk kawin, selanjutnya, Daradjat (2003: 106) mengemukakan bahwa usia muda (remaja) adalah anak yang pada masa dewasa, dimana anak-anak mengalami perubahan-perubahan cepat di segala bidang. Mereka bukan lagi anak-anak baik untuk badan, sikap dan cara berfikir atau bertindak, tetapi bukan pula orang dewasa yang telah matang, masa ini dimulai kira-kira umur 13 tahun dan berakhir kira-kira 21 tahun.

Masa remaja merupakan periode perubahan yang sangat pesat baik dalam perubahan fisiknya maupun perubahan sikap dan perilakunya. Menurut Sabri (2007: 25) ada empat perubahan yang bersifat universal selama masa remaja yaitu:

1. Meningkatnya emosi, intensitasnya tergantung pada tingkat perubahan fisik dan psikologis yang terjadi, perubahan emosi ini hanya pada terjadi pada masa remaja awal.

2. Perubahan fisik, perubahan peran dan minat yang diharapkan oleh kelompok sosial menimbulkan masalah-masalah baru sehingga selama masa ini si remaja merasa ditimbuni masalah.

3. Dengan berubahnya minat dan perilaku, maka nilai-nilai juga berubah. Apa yang dianggap penting dan bernilai pada masa kanak-kanak sekarang ini tidak lagi. Kalau pada masa kuantitas dipentingkan sekarang segi kualitas diutamakan.

4. Sebagian besar remaja bersikap ambivalensi terhadap setiap perubahan. Mereka menginginkan dan menuntut kebebasan, tetapi mereka sering takut bertanggung jawab akan akibatnya dan meragukan kemampuan merekan untuk melaksanakan tanggung jawab tersebut.

Hurlock (dalam Yunus, 2006: 52) mendefinisikan usia remaja dan membaginya dalam tiga tingkatan yaitu: pra remaja 10-12 
tahun, remaja awal 13-16 tahun, remaja akhir 1721 tahun sedangkan dalam ukuran WHO (dalam Wirawan, 1994:9) batasan usia muda terbagi dalam dua bagian yaitu: usia muda awal 10-14 tahun dan usia muda akhir 15-20 tahun.

Ramulyo (1996) mengemukakan tujuan perkawinan adalah untuk memenuhi kebutuhan hidup jasmani dan rohani manusia, untuk membentuk keluarga serta meneruskan keturunan yang sah dalam masyarakat dengan mendirikan rumah tangga yang damai dan teratur.

Ranjabar (dalam Fitrianingsih, 2006:

menjelaskan beberapa faktor yang menyebabkan pernikahan dini antara lain:

1. Faktor kebudayaan

Budaya yang melekat pada diri orang tua menyebabkan orang tua menikahkan anak perempuannya pada usia muda. Faktor budaya memiliki dua indikator yang memengaruhi orang tua menikahkan anak perempuannya di usia muda antara lain:

a. Lingkungan dalam masyarakat yang sangat berpengaruh terhadap terjadinya suatu kebiasaan atau tradisi.

b. Adanya anggapan dalam masyarakat bahwa anak perempuan yang telah berusia remaja dan belum menikah maka akan dianggap perawan tua dan tidak laku. Hal ini juga yang menyebabkan orang tua segera menikahkan anaknya.

2. Tradisi

Termasuk unsur-unsur budaya immaterial seperti cara berpikir, kepercayaan, gaya, atau filsafat. Tradisi berasal dari kata trader yang artinya menyerahkan dan mengirimkan. Jadi tradisi terletak bukan pada antar generasi melainkan transmisi.

3. Adat-istiadat

Adalah dalil atau ajaran mengenai bagaimana orang bertingkah laku dalam masayarakat. Adat dalam pengertian ini berfungsi sebagai dasar pembangunn hukum adat positif yang lain. Istilah adat sering kali diartikan sebagai kebiasan, namun pada dasarnya memiliki arti yang sama, jika mendengar adat-istiadat biasanya aktivitas seseorang dalam masyarakat terjadi secara berulang-ulang dalam jangka waktu tertentu. Suatu adat-istiadat yang hidup dan berkembang dalam masyarakat dan dapat berubah dan diakui sebagai hukum.
4. Faktor rendahnya tingkat pendidikan

Secara umum adalah segala upaya yang dilakukan untuk memengaruhi orang lain baik individu, kelompok atau masyarakat. Menurut Nasution (2010: 24) pendidikan adalah interaksi individu dengan anggota masyarakat, yang berkaitan dengan dan perkembangan yang berhubungan dengan pengetahuan, sikap, kepercayaan, dan keterampilan.

5. Faktor rendahnya tingkat ekonomi

Pernikahan usia muda yang terjadi disebabkan karena alasan mengurangi kebutuhan ekonomi keluarga. Faktor ini berhubungan dengan rendahnya tingkat ekonomi keluarga. Orang tua tidak memiliki kemampuan untuk memenuhi kebutuhan keluarg sihangga orangtua memiliki untuk memercepat pernikahan anaknya, terlebih bagi anak perempuan sehingga dapat mengurangi pemenuhan kebuhuhan keluarga.

Masaroh (dalam Tontowy, 2016: 7) menjelaskan secara luas dampak dari pernikahan usia dini. Sebagai berikut:

1. Dampak fisik atau biologis

Secara biologis alat reproduksi remaja masih dalam proses menuju kematangan sehingga belum siap untuk hubungan seks dengan lawan jenisnya, apalagi jika sampai hamil kemudian melahirkan. Jika dipaksakan akan terjadi trauma, perobekan luas dan infeksi yang akan membahayakan organ reproduksinya, sampai membahayakan jiwa anak.

2. Dampak Psikologis

Secara psikis, remaja juga belum siap dan mengerti tentang hubungan seks, sehingga akan menimbulkan trauma psikis berkepanjangan dalam jiwa remaja yang sulit disembuhkan. Remaja akan murung dan menyesali hidupnya yang akhirnya pada pernikahan yang ia sendiri tidak mengerti atas keputusan hidupnya. Selain itu, ikatan pernikahan akan menghilangkan hak remaja untuk memeroleh pendidikan (wajib 9 tahun), hak bermain dan menikmati waktu luangnya serta hak-hak lainnya yang melekat dalam usia remaja.

3. Dampak Sosial

Fenomena sosial ini berkaitan dengan faktor sosial budaya dalam masayarakat patriarki yang bisa gender, yang menempatkan perempuan pada posisi yang rendah dan hanya dianggap pelengkap seks laki-laki saja. Kondisi ini sangat ini sangat bertentangan dengan ajaran \& norma apapun termasuk agama. Kondisi ini hanya 
akan melestarikan budaya partiarki yang bias gender yang akan melahirkan kekerasan terhadap perempuan.

Hadikusuma (dalam Sardi 2016: 194) menjelaskan bahwa dalam hukum adat pada umumnya tidak mengatur tentang batas umur untuk melaksanakan perkawinan, hal ini berarti hukum adat membolehkan pernikahan untuk semua umur asal sudah dewasa. Kedewasaan seseorang menurut hukum adat diukur dengan tanda-tanda fisik yaitu apabila wanita sudah haidih (datang bulan), buah dada menonjol berarti sudah dewasa, sedang bagi pria ukurannya dapat dilihat dari perubahan suara, parubahan fisik, sudah mengeluarkan air mani atau sudah memunyai nafsu seks. Sudah menjadi kodrat alam bahwa dua orang manusia dengan jenis kelamin yang berlainan, seorang laki-laki dan seorang perempuan, ada daya saling menarik satu sama lain untuk hidup bersama. Antara laki-laki dan perempuan berhubungan dengan maksud untuk mengadakan hubungan pernikahan baik yang berlaku atas kehendak mereka sendiri ataupun karena kehendak orang tua atau keluarga di antara mereka.

\section{Metode Penelitian}

Penelitian ini akan dilaksanakan di SMA Negeri 2 Mawasangka Tengah selama 1 bulan yaitu bulan Oktober 2018. Jenis penelitian ini adalah penelitian kualitatif. Penelitian kualitatif adalah jenis penelitian yang temuan-temuannya tidak diperoleh dari statistik atau bentuk-bentuk hitungan lainnya dan bertujuan mengungkap secara holistik kontekstual melalui pengumpulan data sampai kepada yang lebih jelas, seperti mencari informasi yang mendalam dari hal kecil sampai yang hal yang besar yang menyangkut tentang penelitian atau yang berkaitan dengan penelitian (Sugiyono, 2015: 8).

Informan dalam penelitian ini adalah 1 orang guru BK, 1 guru wali kelas dan 5 siswa yang tercatat mengalami pernikahan usia dini. Data dalam penelitian ini dikumpulkan dengan teknik wawancara. Teknik wawancara dilakukan untuk memeroleh data-data tentang penyebab pernikahan di usia muda yang dilakukan oleh siswa SMA Negeri 2 Mawasangka Tengah. Wawancara dilakukan dengan subyek penelitian sebagai berikut:

1. Guru BK, dimaksudkan untuk memeroleh informasi tentang data siswa yang menikah saat masih sekolah melalui Guru BK.
2. Wali kelas, dimaksudkan untuk mendapat informasi tentang penyebab siswa melakukan pernikahan di usia muda di SMA Negeri 2 Mawasangka Tengah.

3. Siswa, dimaksudkan untuk mengetahui kondisi riil mengenai fenomena yang terjadi.

Data yang diperoleh akan dianalisis dengan metode analisis deskriptif kualitatif, yaitu penyajian data dalam bentuk tulisan, dan menerangkan apa adanya sesuai dengan data yang diperoleh dari hasil penelitian, langkah terakhinya adalah menarik kesimpulan. Langkah-langkah analisis data kualitatif menurut Miles \& Huberman (dalam Sugiyono, 2016: 337) penelitian ini adalah sebagai berikut.

1. Reduksi data

Proses analisis data dimulai dengan menelaah seluruh data yang tersedia dari berbagai sumber. Setelah dikaji, langkah berikutnya adalah membuat rangkuman untuk setiap kontak atau pertemuan dengan responden. Kemudian peneliti membuat abstraksi, yaitu membuat ringkasan yang inti, proses, dan persyaratan yang berasal dari responden tetap dijaga.

Data yang direduksi antara lain seluruh data mengenai permasalahan penelitian, data yang di reduksi akan memberikan gambaran yang lebih spesifik dan memermudah peneliti melakukan pengumpulan data selanjutnya serta mencari data tambahan jika diperlukan.

2. Penyajian data

Pada proses ini peneliti berusaha menyusun data yang relevan, sehingga menjadi informasi yang dapat disimpulkan dan memiliki makna tertentu dengan cara menampilkan dan membuat hubungan antar variabel agar peneliti lain atau pembaca laporan penelitian mengerti apa yang telah terjadi dan apa yang perlu ditindaklanjuti untuk mencapai tujuan penelitian.

Pada proses display data, data perlu diarahkan agar data hasil reduksi terorganisaikan, tersusun dalam pola hubungan sehingga makin mudah dipahami. Penyajian data dapat dilakukan dalam bentuk uraian naratif, bagan, hubungan antar kategori serta diagram alur. Penyajian data dalam bentuk tersebut memermudah peneliti dalam memahami apa yang terjadi. Pada langkah ini, peneliti berusaha menyusun data yang relevan sehingga informasi yang 
didapat disimpulkan dan memiliki makna tertentu untuk menjawab masalah penelitian.

3. Menarik kesimpulan atau verifikasi data

Tahap ini merupakan tahap penarikan kesimpulan dari semua data yang telah diperoleh sebagai hasil dari penelitian. Penarikan kesimpulan atau verifikasi adalah usaha untuk mencari atau memahami makna/ arti, keteraturan, pola-pola, penjelasan, alur sebab akibat. Sebelum melakukan penarikan kesimpulan terlebih dilakukan reduksi data, penyajian data serta penarikan kesimpulan atau verifikasi dari kegiatan-kegiatan sebelumnya.

\section{Hasil Penelitian dan Pembahasan Hasil penelitian}

Berdasarkan hasil pengolahan data yang diperoleh, diperoleh 3 faktor utama siswa SMA Negeri 2 Mawasangka Tengah melakukan pernikahan usia muda meliputi faktor ekonomi, faktor kesadaran pentingnya pendidikan dan faktor pengaruh lingkungan sekitar.

1. Faktor ekonomi

Orang tua menikahkan anaknya yang masih muda karena faktor ekonomi yaitu untuk memenuhi kebutuhan atau kekurangan biaya hidup orang tuanya. Selain itu orang tua menganggap bahwa dengan menikahkan anaknya yang masih di bawah umur akan mengurangi beban ekonomi keluarga. Sebab dengan menyelenggarakan perkawinan akan membuat beban ekonomi keluarga menjadi berkurang karena anak telah membentuk keluarga sendiri.

2. Faktor rendahnya kesadaran terhadap pentingnya pendidikan.

Orang tua menikahkan anak yang masih usia muda tidak hanya karena keadaan ekonomi yang kurang mampu, tetapi rendahnya kesadaran orang tua terhadap pentingnya pendidikan anak pun menjadi salah satu pemicu berlangsungnya sebuah perkawinan. Dengan pendidikan orang tua yang hanya lulus sekolah dasar bahkan ada juga yang tidak sekolah sama sekali (buta huruf) dengan mudahnya untuk segera melangsungkan sebuah perkawinan kepada anak-anaknya. Karena orang tua yang kurang mengerti ataupun memahami sebuah perkawinan yang ideal, orang tua yang hanya lulus sekolah dasar atau tidak sekolah sama sekali (buta huruf) ia hanya melihat anak yang sudah besar sehingga ia berfikir sudah waktunya untuk menikah.

3. Faktor lingkungan tempat mereka tinggal

Orang tua menikahkan anak bukan hanya karena keadaan ekonomi, rendahnya kesadaran orang tua terhadap pendidikan, dan kekhawatiran orang tua akan tetapi lingkungan tempat mereka tinggal pun sangat memengaruhi pola pikir mereka (orang tua maupun anak). Keluarga yang memunyai anak perempuan maupun laki-laki, lebih-lebih anak perempuan belum memiliki pendamping (pacar) melihat anak yang seusia anaknya sudah memiliki pendamping (pacar) apalagi sudah menikah maka orang tua merasa cemas, dan gelisah, ia berusaha mencarikan pendamping (pacar) untuk anaknya.

\section{Pembahasan}

Berdasarkan hasil wawancara yang diperoleh peneliti bahwa perkawinan usia muda di SMA Negeri 2 Mawasangka Tengah masih terjadi. Walaupun siswa yang melangsungkan perkawinan rata-rata umurnya 16 tahun ke atas dan sesuai dengan Undang-undang Perkawinan No 1 Tahun 1974 pasal 7 ayat (1) yaitu pihak pria mencapai umur 19 (sembilan belas) tahun dan pihak wanita sudah mencapai usia 16 (enam belas) tahun. Berdasarkan data hasil penelitian, diperoleh 3 faktor penyebab siswa melakukan pernikahan di usia muda yaitu faktor ekonomi, faktor rendahnya kesadaran terhadap pentingnya pendidikan dan faktor lingkungan tempat mereka tinggal.

Faktor pertama adalah faktor ekonomi. Beban ekonomi keluarga seringkali mendorong orang tua untuk segera menikahkan anaknya dengan harapan beban ekonomi keluarga akan berkurang, karena anak perempuan yang sudah nikah menjadi tanggung jawab suami (BKKBN, 2016). Hal ini sering dijumpai di pedesaan tetapi sekarang ini banyak juga di perkotaan, tanpa peduli usia anaknya yang belum menginjak usia dewasa, orang tua hanya mengizinkan saja karena untuk meringankan beban keluarga. Sehubungan dengan hal ini biasanya orang tua tidak memikirkan usia anaknya, yang mereka pikirkan hanya menikahkan anaknya. Apalagi ketika yang datang melamar adalah dari keluarga kaya, dengan harapan dapat meningkatkan derajatnya (https://www.kompasiana.com, 2018).

Faktor kedua adalah kurangnya pengetahuan orang tua tentang pendidikan sehingga sering kali 
orang tua hanya bersikap pasrah dan menerima keputusan anaknya yang ingin putus sekolah, hal ini mengakibatkan terjadinya rendahnya tingkat pendidikan dan mengakibatkan terjadinya pernikahan dini karena tidak adanya kegiatan positif yang dilakukan anaknya. Menurut Saker dan Rahman (2012) pendidikan merupakan faktor yang paling penting berhubungan dengan pernikahan dini.

Sebagai faktor terakhir, pengaruh dari lingkungan ini sangat kuat apalagi yang berasal dari pola pikir masyarakat dan kurangnya pengetahuan tentang menikah muda dalam pernikahan sering terjadi misalnya adanya kekhawatiran orang tua kepala anak perempuannya yang sudah menginjak remaja walaupun usia anaknya belum mencapai dewasa atau masih di bawah umur, biasannya orang tua yang tinggal baik di pedesaan maupun perkotaan apabila anak perempuannya tidak lagi bersekolah dan tidak memunyai kegiatan yang positif maka pada umumnya akan menikahkan anaknya tersebut cepat-cepat karena takut akan menjadi perawan tua. Sehingga terkadang orang tua akan segera menikahkan anaknya dengan begitu orang tua tidak merasa malu lagi karena anaknya sudah laku dan sesuai dengan pola pernikahan masyarakat sekitarnya.

\section{Kesimpulan dan Saran Kesimpulan}

Berdasarkan data hasil penelitian, faktor penyebab terjadinya pernikahan dini pada siswa SMA Negeri 2 Mawasangka Tengah dapat disimpulkan sebagai berikut:

1. Faktor ekonomi, karena keadaan keluarga yang hidup dalam keadaan sosial ekonimi yang rendah/ kurang sehingga siswa ingin segera menikah agar dapat meringankan beban ekonomi keluarga.

2. Orang tua maupun anak tidak memikirkan betapa pentingnya pendidikan bagi anakanaknya untuk mencapai masa depan yang lebih baik. Pengetahuan orang tua maupun anak yang masih kurang, karena rendahnya pendidikan yang mereka miliki khususnya tentang seluk beluk sebuah perkawinan.

3. Faktor lingkungan tempat mereka tinggal, Perkawinan di usia muda dilakukan siswa karena memang di lingkungan tempat tinggalnya terdapat beberapa orang yang menikah di usia muda dan itu sebagai suatu hal yang biasa untuk dilangsungkan.

\section{Saran}

1. Bagi Masyarakat, harus ada kesadaran dari masyarakat setempat arti penting pendidikan, karena pendidikan sangat besar pengaruhnya terhadap kehidupan.

2. Bagi siswa, hendaknya menghindari pernikahan di usia muda atau pada saat masih usia sekolah. Sebaiknya lebih memertimbangkan lagi dengan matang untuk segera melangsungkan perkawinan, alangkah baiknya dapat meneruskan pendidikan yang lebih tinggi hingga perguruan tinggi.

3. Bagi para orang tua, orang tua memberikan bimbingan kepada putra putrinya tentang arti penting pendidikan untuk meraih masa depan dan menganjurkan supaya anaknya melanjutkan sekolah dan jangan terburuburu untuk melangsungkan perkawinan sebelum benar-benar siap baik secara fisik maupun mental.

4. Bagi guru di SMA Negeri 2 Mawasangka Tengah, agar selalu memberikan wawasan tentang pentingnya pendidikan bagi masa depan dan memberikan informasi tentang dampak negatif pernikahan di usia dini.

\section{Daftar Pustaka}

Ahmad. (2011). Dampak Sosial Pernikahan Usia Dini Studi Kasus di Desa Gunung SindurBogor. Skripsi. UIN Syarif Hidayatullah.

Basyir. Ahmad Azhar. (2004). Hukum Pernikahan Islam. Yogyakarta: UII Press.

BKKBN, (2016). Profil Hasil Pendataan Keluarga Tahun 2016. Jakarta: Direktorat Pelaporan dan Statistik.

Daradjat, Zakiah. (2003). Kesehatan Mental. Cetakan ke-3. Jakarta: Gunung Agung.

Fitrianingsih, Rani. (2006). Faktor-faktor Penyebab Pernikahan Usia Muda Perempuan Desa Sumberdanti Kecamatan Sukowono Kabupaten Jember. Skripsi: Universitas Jember.

Hussein. Muhammad. (2008). Keluarga Sakinah Kesetaraan Relasi Suami Istri. Jakarta: Rahima.

Nasir, Salihun A. (1999). Peranan Pendidikan Agama Terhadap Pemecahan Problem Remaja, Cet ke-1. Jakarta: Kalam Mulia. 
Novita, Ika. (2015). Dampak Psikis Pernikahan Dini dan Pentingnya Bimbingan Pranikah oleh Badan Penasehat Pembinaan dan Pelesatarian Perkawinan Kantor Urusan Agama Kecamatan Cluwak Kabupaten Pati (Suatu Kajian Dalam Bimbingan Dan Konseling Keluarga Islam). Skripsi: UIN Walisongo Semarang.

Poerwadarminta, (1997). Kamus Umum Bahasa Indonesia. Jakarta: PN. Balai Pustaka.

Ramulyo, Idris. (1996). Hukum Perkawinan Islam. Jakarta: PT. Bumi Aksara.

Sabri, Muhamad Alisuf. (2007). Psikologi Pendidikan, Cetakan Ke-3. Jakarta: Pedoman Ilmu Jaya.

Sardi, B. (2016). Faktor-faktor Pendorong Pernikahan Dini dan Dampaknya di Desa Mahak Baru Kecamatan Sungai Boh Kabupaten Malinau. eJournal SosiatriSosiologi, 2(1), 196.

Sari, Veronica Sovita, Suwarsito Suwarsito, dan Mustolikh Mustolikh. (2015). Kajian Faktor-faktor Penyebab Perkawinan Usia Muda dan Dampaknya Terhadap Kondisi Sosial Ekonomi di Desa Lebakwangi Kecamatan Pagedongan Kabupaten Banjarnegara. Jurnal Penelitian Geoedukasi volume nomor 2 tahun 2015. hal 19-23.

Sarwono, Sarlito Wirawan. (2007). Psikologi Remaja. Jakarta: Raja Grafindo Persada.

Shomad. Abdul. (2010). Hukum Islam (Penormaan Prinsip Syariah dalam Hukum Indonesia). Jakarta: Kencana Prenada Media Group.

Soemiyati. (2007). Hukum Perkawinan Islam Dan Undang-Undang Perkawinan (UndangUndang Perkawinan No. 1 Tahun 1974, Tentang Perkawinan). Yogyakarta: Liberty.

Sugiyono. (2015). Metode Penelitian Kombinasi (Mix Methods). Bandung: PT Alfabeta.

2016. Metode Penelitian Kuantitatif, Kualitatif dan $R \& D$. Bandung: PT Alfabeta.
Sungkuwula, Dede Saban. (2015). Persepsi Masyarakat Terhadap Perkawinan Usia Dini. Skripsi. STAIN Kendari.

Undang-undang Perkawinan Republik Indonesia Nomor 1 Tahun 1974. 